\title{
Metrik Kompleksitas Software Berorientasi Objek
}

\author{
Kalvin Niam Aunillah ${ }^{1, *}$, Akbar Roihan ${ }^{2}$, Hikmah Damasta Ribilanam $^{3}$, Muhammad Ainul Yaqin ${ }^{4}$ \\ Jurusan Teknik Informatika, Universitas Islam Negeri Maulana Malik Ibrahim, Indonesia \\ ${ }^{1} 17650060 @$ student.uin-malang.ac.id; ${ }^{2} 17650006 @$ student.uin-malang.ac.id; ${ }^{3} 17650062 @$ student.uin-malang.ac.id; \\ 4yaqinov@ti.uin-malang.ac.id; \\ *corresponding author
}

INFO ARTIKEL

Sejarah Artikel

Diterima: 24 Desember 2020

Direvisi: 20 Januari 2021

Diterbitkan: 30 April 2021

Kata Kunci

Object Oriented

Metrik Kompleksitas

Kompleksitas Software

\section{ABSTRAK}

Teknologi sudah banyak berperan andil besar dalam meringankan pekerjaan manusia saat ini, teknologi diperkirakan akan terus berkembang. Software merupakan salah satu contoh dari perkembangan teknologi yang sampai sekarang banyak digunakan. Hal ini yang menyebabkan teknik pengembangan software semakin berkembang, dahulu developer menggunakan teknik procedural programming namun teknik ini mulai tidak praktis untuk bekerja dalam tim hingga dikenal teknik object oriented atau dalam pemrogaman disebut object oriented progamming. Berorientasi objek atau object oriented mulai banyak diterapkan karena lebih mempermudah developer saat bekerja dalam bentuk tim. Dikarenakan semakin banyak pengguna teknik object oriented dibutuhkan formula baru untuk menghitung kompleksitas software berorientasi objek, hal ini dikarenakan formula yang diajukan peneliti sebelumnya lebih mengarah formula untuk menghitung kompleksitas software berbasis procedural. Selain itu, mengetahui kompleksitas metrik dibutuhkan agar mempermudah developer untuk mengetahui kualitas dari software buatannya. Metrik yang diajukan pada penelitian ini memperhitungkan aspek dari relasi antar class, method, attribute dan bobot class. Metrik yang kami usulkan menghitung kompleksitas berorientasi objek berdasarkan diagram UML (Unified Modeling Language) untuk memodelkan sistemnya dan direpresentasikan ke dalam bentuk WDAG. Setelah itu, metrik akan divalidasi menggunakan dasar teori sembilan properti Weyuker. Setelah dilakukan validasi, hasil yang didapat adalah delapan dari sembilan properti Weyuker terpenuhi.

\section{PENDAHULUAN}

Teknologi merupakan salah satu ciptaan manusia yang terus mengalami perkembangan, salah satu contoh produk teknologi yakni software. Software berperan sebagai sebagai suatu penjembatan antara hardware (perangkat keras) dengan pengguna, karena itu software dapat membantu meringankan pekerjaan manusia melalui hardware hingga sampai saat ini. Selain itu teknologi diperkirakan akan terus berkembang hingga dapat bepikir dan merasakan[1]. Object oriented (OO) merupakan suatu teknik perancangan sistem software dengan pendekatan program yang berorientasi objek, OO sering juga disebut object oriented progamming dalam aspek syntax program (OOP) [2].

OO sering digunakan developer saat perancangan sistem software, hal ini dikarenakan dapat mempermudah saat bekerja dalam tim. Kompleksitas suatu software harus diketahui oleh para developer, dikarenakan selain untuk mengetahui nilai kompleksitas juga dapat dijadikan penentu atau patokan harga suatu sotware. Semakin kompleks suatu software maka semakin tinggi atau besar harga software, dalam paper ini akan membahas mengenai metrik 
kompleksitas software berorientasi objek melalui perhitungan dari diagram UML lalu didokumentasikan dalam graph.

Pada perkembangannya, metrik kompleksitas software berorientasi objek terdapat istilah yakni Object oriented Complexity Metric (OOCM) merupakan metrik yang mengukur kompleksitas dan kerumitan software yang berorientasi objek. OOCM sudah banyak diajukan oleh peneliti. Akan tetapi, kebanyakan rumus yang digunakan belum cukup efektif untuk mengukur kompleksitas hingga pengembangan rumus saat ini. Pemrograman berorientasi objek (OOP) telah mendominasi bidang pemrograman perangkat lunak selama beberapa dekade terakhir. Perbaikan dan modifikasi dalam teknik-teknik ini masih menjalani penelitian [3], sehingga masih belum ada metrik yang menggunakan pendekatan graph dalam perhitungannya. Development software OOP berbeda dengan devolempent tradisional, yang berbeda adalah teknik dalam pengembangannya [4]. Oleh sebab itu, paper ini mengajukan metrik kompleksitas berorientasi objek dengan pendekatan graph. Pendekatan ini dilakukan berdasarkan diagram UML dengan cara mengukur kompleksitas berorientasi objek yang didasarkan pada bobot class yang dihubungkan oleh relasi antar class. Dengan demikian, hasil perhitungan metrik kompleksitas berorientasi objek diperoleh dari perbandingan terbalik antara Tm dan WCC. Tahap terakhir adalah validasi metrik menggunakan teori sembilan Weyuker's Properties.

\section{METODE}

\section{Identifikasi Metrik Menggunakan Goal Question Metrics (GQM)}

Untuk memudahkan identifikasi dan penggambaran penelitian, peneliti menerapkan Goal Question Metrics (GQM). Metode dimulai dari goal measurement dilanjutkan serangkaian pertanyaan untuk setiap goal, dimana setiap pertanyaan akan dijawab apabila goal tercapai[8], sebagaimana ditampilkan pada Tabel 1 dan Tabel 2.

Tabel 1. Goal Measurement

\begin{tabular}{ll}
\hline Analysis & $\begin{array}{l}\text { Mengukur kompleksitas software berorientasi } \\
\text { objek. }\end{array}$ \\
Issue & $\begin{array}{l}\text { Untuk dapat mendapatkan besaran nilai } \\
\text { kompleksitas dari suatu software berorientasi objek. }\end{array}$ \\
$:$ & Class, method, attribute, Relasi kelas, Jumlah \\
Focus of measurement & Child, Tingkat kedalaman pewarisan. \\
$:$ & Progammer \\
Point of view & Kualitas suatu software dapat dinilai melalui \\
$:$ & struktur didalamnya. \\
\hline
\end{tabular}

Tabel 2. Identifikasi goal kompleksitas software berorientasi objek

Q.1 Apa yang membentuk berorientasi objek?

M.1 Class dan relasi

Q.2 Apa yang membentuk sebuah Class?

M.2 Methods dan attributes

Q.3 Apa saja jenis relasi?

M.3 Inheritance, Association, Aggregation, Composition dan Interface

Q.4 Apa saja metrik berorientasi objek yang pernah diajukan?

M.4 Graph dan jenis relasi 


\section{Tinjauan ulang formula kompleksitas}

Merepresentasi kompleksitas berorientasi objek, dengan mempertimbangkan beberapa hal yakni penelitian terdahulu menngenai kompleksitas method dan jumlah atribut di dalam kelas[5]. Serta penelitian Chidamber \& Kemerer yang merepresentasikan kompleksitas berorientasi objek, dengan memperthitungkan [6][7]:

1. WMC (Weight Method Class)

2. DIT (Depth of Inheritance Tree)

3. RFC (Response for a Classes)

4. LCOM (Lack of Cohesion Of Methods)

5. NOC (Number Of Children)

6. CBO (Coupling Between Object Classes)

Sedangkan perbandingan formula kompleksitas dalam bentuk Tabel 3.

Tabel 3. Metrik-metrik yang telah disertakan dalam formula kompleksitas

\begin{tabular}{lccccccccccc}
\hline & C & M & A & R & WM & DIT & NOC & CB & RFC & $\begin{array}{c}\text { LCO } \\
\text { M }\end{array}$ \\
\cline { 2 - 9 } $\begin{array}{l}\text { Chidamber dkk., } \\
\mathbf{1 9 9 4}\end{array}$ & - & $\sqrt{ }$ & - & - & $\sqrt{ }$ & $\sqrt{ }$ & $\sqrt{ }$ & $\sqrt{ }$ & $\sqrt{ }$ & $\sqrt{ }$ \\
$\begin{array}{l}\text { Sanjay dkk., 2008 } \\
\begin{array}{l}\text { Metrik yang } \\
\text { diusulkan }\end{array}\end{array}$ & - & $\sqrt{ }$ & $\sqrt{ }$ & - & - & - & - & - & - & - \\
\hline
\end{tabular}

Tabel 3 merupakan perbandingan formula kompleksitas setiap usulan dari penemu, dari tabel tersebut diketahui formula setiap metrik yang diusulkan. pada metode metrik kompleksitas Chidamber belum diperhitungkan formula dari kuantitas class, attribute dan relasi. Sedangkan metode Sanjaya, belum memperhitungkan formula kuantitas class, relasi, dan kriteria yang mencangkup OOP dari Chidamber \& Kemerer. Sedangkan metode yang paper ini usulkan, memiliki formula lebih lengkap dari metode yang Chidamber \& Kemerer dan Sanjay usulkan.

\section{Perhitungan dengan Weighted Class Complexity (WCC)}

Perhitungan metrik diawali dengan mencari nilai Weighted Class Complexity (WCC) dikarenakan WCC merupakan perhitungan kompleksitas yang berkaitan dengan Method Complexity dalam class terkait. Nilai bobot kognitif yang didapat berasal dari method class. Kemudian ditambah dengan total jumlah attributes dari class tersebut. Maka, akan menambah kompleksitas karena faktor data members (attributes). Rumus formula seperti halnya Persamaan (1).

$$
W C C=N_{a}+\sum_{p=1}^{i} M C p
$$

Keterangan:

- $\mathrm{Na}$ adalah jumlah attribute class

- MC kompleksitas method pada class

Pada penelitian ini, kami menggunakan studi kasus UML aplikasi penduduk desa berbasis object oriented seperti tampak pada Gambar 1. Selain dikarenakan UML aplikasi ini berbasis object oriented, aplikasi ini layak untuk diketahui tingkat kompleksitasnya untuk meningkatkan dan pengembangan pelayanan di desa. 


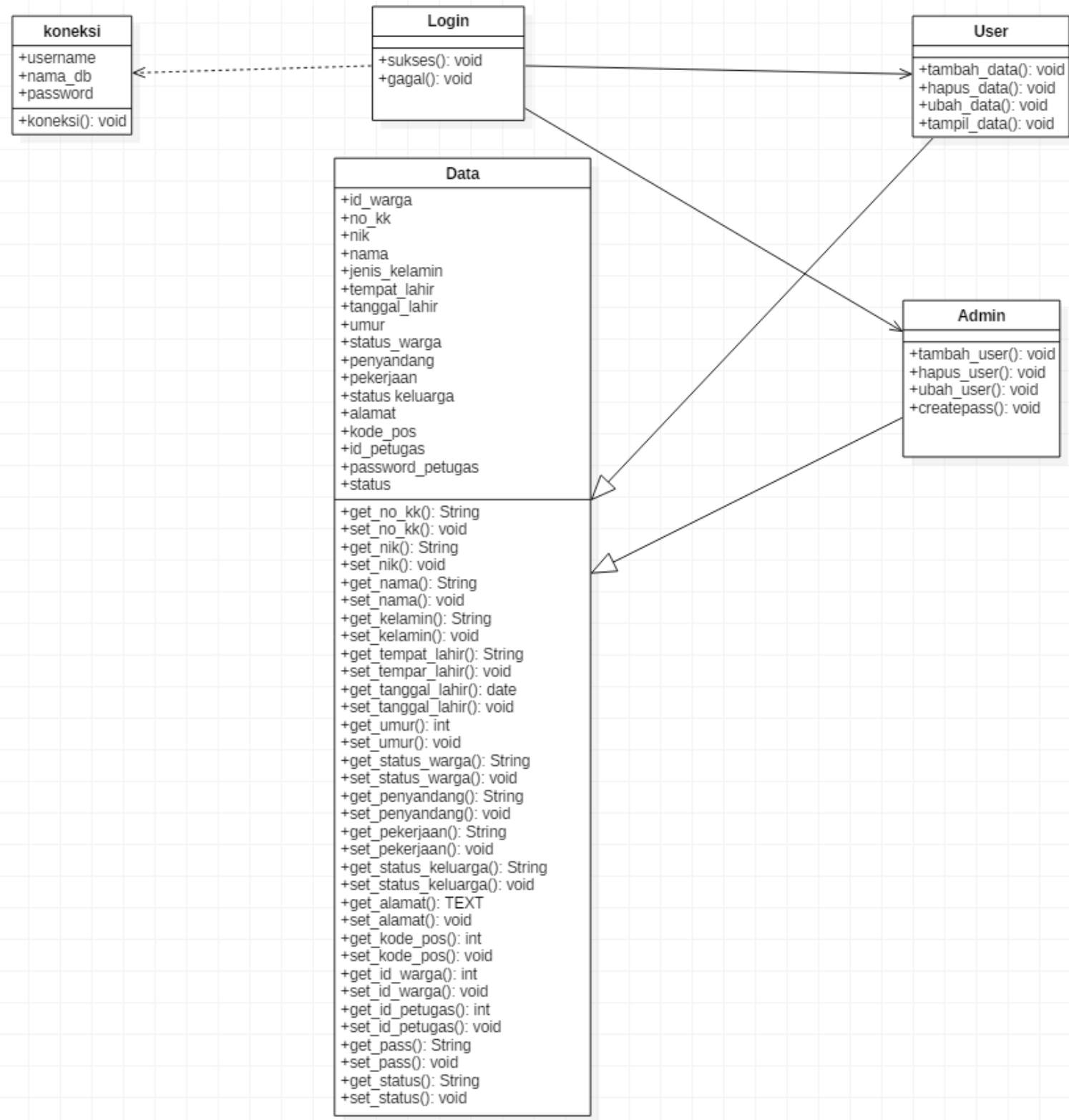

Gambar 1. Model UML aplikasi penduduk desa

Berdasarkan UML tersebut, langkah pertama mencari jumlah attribute class (Na), kemudian langkah kedua menghitung total jumlah kompleksitas method pada satu class. Tabel 4 merupakan hasil dari perhitungan WCC berdasarkan UML pada Gambar 1.

Tabel 4. Hasil dari perhitungan WCC

\begin{tabular}{cccc}
\hline Class & Na & Mc & WCC \\
\hline koneksi & 3 & 1 & 4 \\
Login & 0 & 2 & 2 \\
Admin & 0 & 4 & 4 \\
User & 0 & 4 & 4 \\
Data & 17 & 34 & 51 \\
\hline
\end{tabular}

Diketahui hasi WCC dari hasil perhitungan didapati class warga memiliki kompleksitas yang besar dengan nilai 42, sedangkan WCC terendah yakni class Login dengan nilai sebesar 
2. Langkah selanjutnya dengan menghitung OOC (Object oriented Complexity) dengan direpresentasikan dalam bentuk WDAG (Weighted Directed Acyclic Graph).

\section{Perhitungan OOC dengan dengan Representasi WDAG}

Proses perhitungan selanjutnya dengan menghitung relasi antar class, WDAG pada penelitian ini berperan sebagai pendokumentasi kompleksitas. WDAG merupakan graph berarah yang memiliki bobot dan terdiri dari himpunan simpul (Nodes atau vertices) dan sisi (Edges atau arcs) yang tidak memiliki cycle. Penggunaan konsep WDAG dalam penelitian yakni:

1. Pada WDAG terdiri atas:

- Leaf nodes, merepresentasikan class atau objek beserta bobotnya.

- Interior Nodes, merepresentasikan operasi atau operator (tergantung jenis relasi).

2. Sebuah node baru, dibuat dan dihubungkan dengan Interior Node hanya ketika class atau objek mempunyai relasi dengan objek lainnya.

Sedangkan formula rumus untuk menghitung jumlah relasi sesuai pada persamaan (2).

$T m=(C, t 1 \ldots \mathrm{tm})$

Keterangan:

- m adalah jumlah relasi antar class

- C adalah himpunan WCC (e.g., bilangan real)

- $\mathrm{t}$ adalah operator binary $\left(\right.$ e.g.,,$\left.+{ }^{*}\right)$ terhadap elemen-elemen dari C.

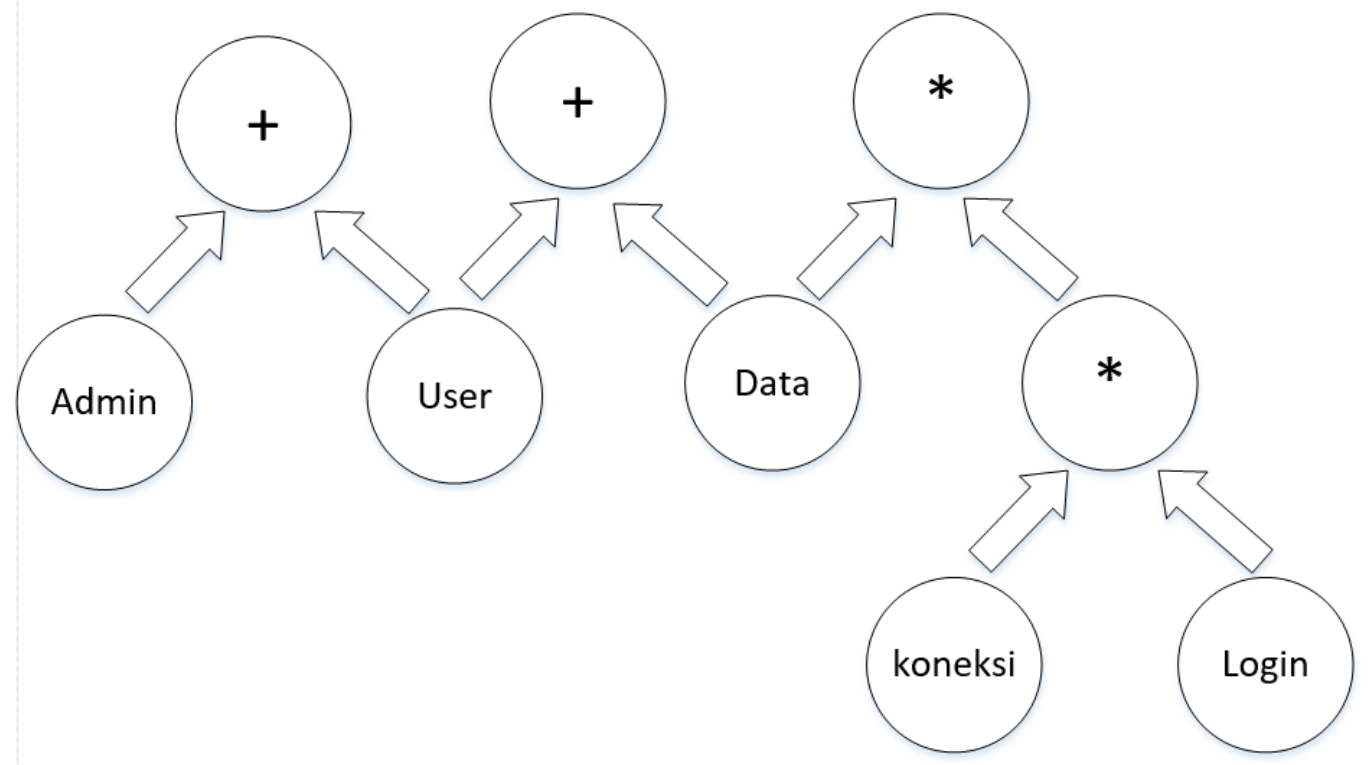

Gambar 2. Hasil pendokumentasi kompleksitas dalam bentuk WDAG

Studi kasus ini apabila dibentuk dalam WDAG sesuai dua konsep diatas, sesuai pada gambar 2. Hasil dari perhitungan relasi antar class (Tm) yakni hasil pengoperasian WCC sesuai dengan operator WDAG pada gambar 2. Sehingga, untuk studi kasus ini $4+4+51 *(4 * 2)=416$. Langkah selajutnya dengan menghitung OOC, dengan rumus Persamaan (3). 


$$
O O C=\frac{T m}{\sum_{i=1}^{n} W C C}
$$

Keterangan:

- $\mathrm{T}_{\mathrm{m}}$ adalah total bobot dari DAG

- WCC adalah Weighted Class Complexity

Menggunakan persamaan (3), maka diketahui OOC pada studi kasus ini merupakan hasil pembagian 416 dengan total keselurahan jumlah WCCyakni 65. Sehingga, nilai kompleksitas berdasarkan UML pada studi kasus aplikasi penduduk desa sebesar 6,4.

\section{HASIL DAN PEMBAHASAN}

Perhitungan Berdasarkan Gambar 2, dilanjutkan dengan perhitungan hasil akhir kompleksitas sesuai pada persamaan (3) dengan pembagian total bobot DAG sebesar 416 dan jumlah WCC sebesar 65. Sehingga, nilai kompleksitas berdasarkan UML pada studi kasus aplikasi penduduk desa sebesar 6,4. Setiap metrik baru harus divalidasi dan dievaluasi baik secara teori maupun praktek. Tujuan validasi adalah untuk membuktikan ketepatan dari metrik yang diusulkan. Oleh karena itu, kami sebagai pengusul metrik memeriksa metrik yang kami usulkan terhadap sembilan properti Weyuker yang terkenal [9]. Meskipun, 9 properti ini sangat banyak dikritik oleh beberapa peneliti, 9 properti ini masih digunakan dan menjadi topik penelitian[10].

\section{Properties Pertama}

Kompleksitas metrik yang diajukan mampu membedakan antara dua model proses yang tidak sama sehingga menciptakan hasil metrik yang berbeda. Berdasarkan statement tersebut, pengukuran tidak boleh dilakukan pada class dengan kompleksitas yang sama. Misal, diketahui pada tabel 2, class C dengan kompleksitas 6 dan class D dengan kompleksitas 3, dimana $\mathrm{C}$ dan $\mathrm{D}$ adalah class yang berbeda. Dengan demikian, properti ini terpenuhi.

\section{Properties Kedua}

Pengajuan metrik kompleksitas memiliki sifat positif. Properties ini juga berlaku, apabila saat melakukan perhitungan WCC. Hasilnya berupa angka yang positif (tabel 4) begitu juga dengan perhitungan akhir OCC memilik sifat angka positif yakni 6,4. Sehingga properti ini terpenuhi.

\section{Properties Ketiga}

Jika ada beberapa dua model yang terdapat perbedaan (proses bisnis) memungkinkan memiliki nilai kompleksitas yang sama. Berdasarkan hal ini , seperti yang tampak pada tabel 4 dapat diketahui ada dua class atau bisa disebut dua model. Keduanya memiliki bisinis yang berbeda, tapi nilai WCC keduanya yakni admin dan user sama yakni 4. Maka property ini telah terpenuhi.

\section{Properties Keempat}

Metrik kompleksitas dapat membedakan suatu model yang memiliki proses bisnis sama namun berbeda dalam implementasinya. Misal terdapat class $\mathrm{P}$ dan $\mathrm{Q}$ yang menghasilkan output yang berbeda dengan input yang sama. Karena pada bobot kognitif bergantung pada elemen internal class (attribute dan method), sehingga kompleksitas juga mungkin berbeda. Seperti yang tampak pada Tabel 4 dan secara keseluruhan pada Gambar 2, terdapat proses 
model bisnis yang class sama namun berbeda implementasi (relation). Maka, dengan demikian properti ini juga terpenuhi.

\section{Properties Kelima}

Metrik kompleksitas dapat terdiri dari elemen penggabungan yang baru. Pada Persamaan (3) merupakan hasil penggabungan elemen baru, eleman baru yang dimaksud adalah WCC dari class admin, user, login, koneksi dan data. Sehingga dengan demikian properti ini terpenuhi.

\section{Properties Keenam}

Apabila terdapat model proses bisnis $X, Y$, dan $Z$ dengan nilai metrik yang sama, lalu model A dikaitkan dengan model $\mathrm{Z}$ atau model $\mathrm{Y}$ dikaitkan dengan model $\mathrm{Z}$. Maka kedua nilai metrik berbeda. Ini berarti bahwa jika class baru ditambahkan ke kedua class yang memiliki kompleksitas class yang sama, maka kombinasi kompleksitas kedua class tersebut berbeda.

Misal: $W C C$ class $\mathrm{X}=4, W C C$ class $\mathrm{Y}=4, W C C$ class $\mathrm{Z}=6, W C C$ class $\mathrm{N}=3$.

$\mathrm{X}=\mathrm{Y}, \&(\mathrm{X} * \mathrm{Z}) \neq(\mathrm{Y} * \mathrm{Z}) \quad \square 4=4, \& 24 \neq 12$

$X=X, \&(Z * X) \neq(Z * Y) \quad \square 4=4, \& 24 \neq 12$

Maka, metrik yang kami ajukan belum memenuhi properti ini.

\section{Properties Ketujuh}

Apabila membandingkan dua model bisinis yang mana masing-masing kesatuan yang utuh. Jika salah satu proses bisinis berbeda dalam atat letak model. Maka berbeda pula nilainuya, maka metrik yang kami ajukan dapat memenuhi properti ini.

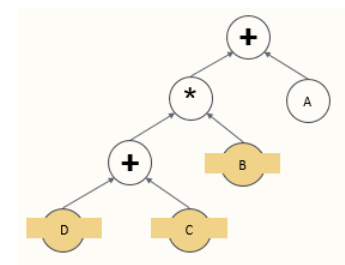

Gambar 3. WDAG 2

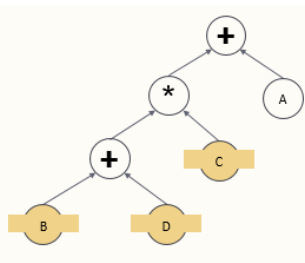

Gambar 4. WDAG 3

Tm dari gambar WDAG $1=\mathrm{A}+(\mathrm{B} *(\mathrm{C}+\mathrm{D}))$ dan Tm dari gambar WDAG $2=\mathrm{A}+((\mathrm{B}+$ D) $*$ C ). Maka, properti ini terpenuhi.

\section{Properties Kedelapan}

Properti ini mensyaratkan bahwa ketika nama class berubah itu tidak akan mempengaruhi kompleksitas. Bahkan jika nama method ataupun nama attributes dalam class berubah, kompleksitas juga tidak berubah. Berdasarkan pengukuran kompleksitas yang kami usulkan, tidak ada efek dalam kompleksitas dalam penggantian nama. Dengan demikian, properti ini juga terpenuhi.

\section{Properties Kesembilan}

Properti ini menunjukkan bahwa interaksi tertentu meningkatkan kompleksitas. Properti ini menyatakan bahwa kompleksitas yang berasal dari hasil interaksi antara dua class lebih besar daripada kompleksitas class sebelum berinteraksi. Untuk properti ini, pembuktiannya sama dengan pada properti 5. Maka, dengan demikian properti ini juga terpenuhi. 


\section{KESIMPULAN}

Penelitian ini menghasilkan metrik yang mengukur tingkat kompleksitas software berorientasi objek melalui UML dan pendokumentasian dalam bentuk WDAG. Hasil formula metrik ini memenuhi delapan properties dari sembilan properties yang terdapat di weyuker properties. Formula kompleksitas yang kami ajukan Persamaan (3), dapat digunakan untuk mengukur kompleksitas software khusus berbasis object oriented, harapan kami formula ini dapat melengkapi kekurangan dari formula kompleksitas metrik peneliti sebelumnya yang masih mengarah prosedural programming.

\section{REFERENSI}

[1] Y. Wang, "Cognitive Informatics: Towards Future Generation Computers that Think and Feel," pp. 3-7, 2006.

[2] L. C. Briand and J. Wüst, "Modeling development effort in object-oriented systems using design properties," IEEE Trans. Softw. Eng., vol. 27, no. 11, pp. 963-986, 2001, doi: 10.1109/32.965338.

[3] L. C. Briand, C. Bunse, and J. W. Daly, "A controlled experiment for evaluating quality guidelines on the maintainability of object-oriented designs," IEEE Trans. Softw. Eng., vol. 27, no. 6, pp. 513529, 2001, doi: 10.1109/32.926174.

[4] S. R. Schach, Object-Oriented and Classical Software Engineering. 2010.

[5] G. Costagliola, F. Ferrucci, G. Tortora, and G. Vitiello, "Class point: An approach for the size estimation of object-oriented systems," IEEE Trans. Softw. Eng., vol. 31, no. 1, pp. 52-74, 2005, doi: 10.1109/TSE.2005.5.

[6] S. R. Chidamber and C. F. Kemerer, “A Metrics Suite for Object oriented Design,” IEEE Trans. Softw. Eng., vol. 20, no. 6, pp. 476-493, 1994, doi: 10.1109/32.295895.

[7] K. Letelay and S. N. Azhari, "Evaluasi Kualitas Perangkat Lunak dengan Metrics Berorientasi Objek,” Semin. Nas. Inform. ..., vol. 2012, no. semnasIF, pp. 139-145, 2015.

[8] M. Yaqin, R. Sarno, and S. Rochimah, "Measuring Scalable Business Process Model Complexity Based on Basic Control Structure," Int. J. Intell. Eng. Syst., vol. 13, no. 6, pp. 52-65, 2020, doi: 10.22266/ijies2020.1231.06.

[9] S. Misra, "Weyuker's properties, language independency and object oriented metrics," Lect. Notes Comput. Sci. (including Subser. Lect. Notes Artif. Intell. Lect. Notes Bioinformatics), vol. 5593 LNCS, no. PART 2, pp. 70-81, 2009, doi: 10.1007/978-3-642-02457-3_6.

[10] Gursaran and Gurdev. Roy, "On the Applicability of Weyuker Property 9 to Object-Oriented Structural Inheritance Complexity Metrics,” vol. 27, no. 4, pp. 1-1, 2012, doi: 10.1109/vr.2012.6180941. 